\title{
Toplumsal Teknolojik Gelişmeler Açısından Sosyal Bilimlerin İşlevi ve Toplumla Etkileşimi
}

Kemal ER, İstanbul Gelişim Üniversitesi, İktisadi İdari Bilimler Fakültesi Sosyoloji Bölümü, Dr. Öğr. Üyesi., ker@gelisim.edu.tr, (D) 0000-0002-6906-7129

İsmet Galip YOLCUOĞLU, İstanbul Gelişim Üniversitesi, Uygulamalı Bilimler Yüksek Okulu Sosyal Hizmet Bölümü, Prof. Dr., igyolcuoglu@gelisim.edu.tr, (iD) 0000-0003-3294-7015

$\ddot{O} Z$

Anahtar : Toplumsal Gelişme, Teknolojik Gelişme, Sosyo-ekonomik Gelişme, Toplumsal Kelimeler

\section{The Function of Social Sciences in Terms of Social Technological Development and Its Interaction with Society}

Tarihsel süreçte toplumlar, teknolojideki, kültürdeki, ideolojilerdeki değişimler vb. etkisiyle daha karmaşık toplumsal yapılara doğru evirilmiştir. Fizik bilimlerde, teknolojideki gelişmeler çok hızl gelişmiş, sosyal bilimlerde, kültürde olan değişimler ise aynı hızda ilerleyememiştir. Ancak, bütün bir tarihin de gösterdiği gibi, sosyal bilimler gelişmeden ne fizik bilimlerin ne de sosyo-ekonomik gelişmelerin yerini bulması olanaklı değildir. O nedenle buradaki makalede, öncelikle, bilimsel yaklaşımlar dikkate alınarak, genel olarak bilimin ve sosyal bilimlerin sağlam temeller üzerinde oturması üzerinde durulmuştur. Devamında bazı önemli teorisyenlerin, düşünürlerin görüşlerine de yer verilerek, toplumsal gelişme açısından sosyal bilimlerin işlevi, farklı yaklaşımların düşünce dünyasına kazandırdıkları zenginliklerle anlatılmaya çalışılmıştır. Aynı zamanda toplumlardaki değişmelere dikkat çekilerek, sosyal bilimlerin bu değişimlerle olan ilişkisi, etkileşimi açıklanmaya çalışılmıştır. Buradaki satırlarda yer alan derinliğine incelemeler ve analizlerle toplumsal gelişme açısından sosyal bilimlerin işlevini değerlendirmek makalenin amacıdır. Sağlıklı bir toplumsal gelişme olabilmesi için, sağlıkl bir temelde gelişen sosyal bilimlere ihtiyaç bulunmaktadır. Bu durum ise, konu üzerinde gerçekleştirilen makalenin farkındalık yaratma açısından ne kadar önemli olduğunu açıklamaktadır. Çalışmada literatür taraması yöntemi kullanılmıştır. Incelenen teoriler ve yaklaşımlar, literatür taraması yöntemi benimsenerek, yorum ve analizlerle güçlendirilmek istenmiştir.
ABSTRACT
In the historical process, societies has evolved into more complex social structures with the effect of changes in technology, culture, ideologies, etc. Developments in physical sciences and technology have developed very quickly, on the other hand changes in social sciences and culture have not progressed at the same pace. However, as a whole history has shown, it is not possible for neither physical sciences nor socioeconomic developments to find their place without the development of social sciences. For this reason, in this article, it is primarily emphasized that science and social sciences should be based on solid foundations, taking into account scientific approaches. Subsequently, the views of some important theorists and thinkers were 


\begin{abstract}
also included, and the function of social sciences in terms of social development was tried to be explained with the richness that different approaches brought to the world of thought. At the same time, by drawing attention to the changes in societies, the relationship and interaction of social sciences with these changes has been tried to be explained. It is the aim of the article to evaluate the function of social sciences in terms of social development through in-depth examinations and analyzes in the lines here. In order to have a healthy social development, social sciences developed on a healthy basis are needed. This situation explains how important the article on the subject is in terms of raising awareness. In this study, literature review method was used. The studied theories and approaches were tried to be strengthened by the literature review method, interpretation, and analysis.
\end{abstract}

Keywords : Social Development, Technological Development, Socio-economic Development, Social Change, Social Sciences

\title{
Gíriş
}

Toplumların daha ileri seviyede yaşama seviyelerine gelebilmesinde sosyo-ekonomik gelişme başat rol oynamaktadır. Sosyo-ekonomik gelişme düşünüldüğünde, genelde algısal anlamda, teknoloji paralelinde, özellikle kodlarla yazılımlar üzerinden, tüm üretimin, ekonominin gelişmesi öne çıkmakta; bu durumun sosyal gelişme olarak da topluma yansımaları akla gelmektedir. Ancak dünyadaki tarihsel süreçlere bakıldığında, öncelikle sosyal bilimlerdeki gelişmeler olmadan bilim ve teknolojinin ilerlemesinin, devamında da ekonominin gelişmesinin pek olanaklı olmadığı anlaşılmaktadır. Bu durum sosyal bilimlerin önceliği olduğunu göstermektedir. Çünkü sosyal bilimler olmadan bilimsel öngörünün, bakış açısının olması olanaklı değildir. Söz konusu öngörü ve bakış açısı olmadan da fizik bilimlere de ilgi duymak, dünyayı evreni keşfetmeye, anlamaya istek duymak, insan kaynağını geliştirmek, insan ve insan toplumuyla ilgili maddesel kanıtları bulmaya çalışmak olanaklı değildir. Yani teknolojiyi güçlendiren bilim dallarının gelişmesi için sosyal bilimlerin toplumsal kültürü geliştirmesine ihtiyaç vardır.

Toplumsal gelişmeyle ilgili olarak, tarih sahnesindeki bilinen ilk uygarlıklardan günümüze gelene kadar, tüm uygarlıklarda bilimin toplumsal gelişmeye olan etkisi izlenebilir. Makalede sosyal bilimler ve toplumsal gelişmeyle ilişkisi paralelinde, tarihsel süreçteki gelişmeler, sosyal bilimlerdeki gelişmeler dikkate alınarak; sosyal bilimlerin bilime katkıları, önemli düşünürlerin, bilim insanlarının görüşleri, sosyal bilimlerin toplumsal 
gelişmeye etkisi belirginleştirilmeye çalışılacaktır. Bilindiği gibi dünya toplumlarında, fizik bilimlerdeki gelişmeler, teknolojinin insan hayatına getirdiği kolaylıklar, toplumsal sorunlara çözüm bulamamaktadır. O nedenle buradaki çalışma, her geçen zamanda yenileri eklenen toplumsal sorunlara, sosyal bilimlerin olabilecek katkılarıyla ilgili farkındalık geliştirmeyi, olası çözümlere işaret etmeyi hedeflemektedir. Bu açıdan dikkate alındığında, sosyal bilimlerle ilgili yaklaşımları, sosyal bilimlerin toplumsal sorunlarla ilgili, toplumsal gelişmeyle ilgili katkısını pekiştirme açısından önemlidir. Söz konusu araştırmanın yapılmasında, literatür taraması yöntemi kullanılacak olup, kapsamı daraltma gereği, makale yazarlarının branşlarına da uygun olarak, daha çok sosyoloji ve sosyal çalışma disiplinleri başta olmak üzere, sosyal bilimlerin toplumsal gelişmeye, insan düşüncesinin ileri bakış seviyelerine ulaşmasına, parlamasına etkisi ortaya konmaya çalışılacaktır. Ayrıca sosyal bilimlerin; teknolojinin, internetin, bilişimin, yapay zekânın, tüm üretimin, insan hayatının merkeze oturduğu dünyamızda, fizik bilimlerin gelişmesine katkısı mercek altına alınacaktır.

\section{GENEL HATLARI AÇISINDAN SOSYAL BİLIMLER VE İŞLEVI}

Bilim söz konusu olduğunda çok farklı yaklaşımların olduğunu ve her yaklaşım şeklinin de kendi doğrularını ürettiğini kabul etmek gerekir. Genel bir bilgi olarak bilimde kesinlik olmadığını, doğruların sürekli değişebileceğini baştan içselleştirmek gerekir. Bilimsel kanıtlar, bilgiler, sürekli ve sonsuza kadar sorgulanabilir. Bilimin bu özelliği, bilim konuları ile bilim olmayanların konuları arasında temel belirleyici olandır. Popper’ın görüşlerine göre de bilimde temel amaç teorileri çürütmek üzerinedir. Bir teorinin bilimsel karakteri onun yanlışlanabilirliğiyle ilgilidir. Bilim tarihinin de gösterdiği gibi, bilimde ilerlemeler genellikle bilimsel teorilerin deneylerle, mantık dizgesiyle hatalı yanlarının ortaya konmasıyla gerçekleşmektedir. Hiçbir teorinin sonsuza kadar gerçek olacağı iddia edilemez, ancak mevcut teoriler gerçekleri araştırmamız, seçmemiz açısından olanak sağlar (1971, s. 445, 446). Popper'in görüşleriyle de açıklanmaya çalışıldığı gibi, bir teorinin doğru olması, o teorinin ancak tüm yanlışlamalara ne kadar süre direnebildiğiyle ilgilidir. Yine anlaşılacağı gibi bir bilginin bilimin konusu olması için, yanlışlanabilme özelliği olması, yanlışlanabilirliğinin iddia edilebilmesi; bilim insanlarınca doğruluğu ya da yanlışlığıyla ilgili tüm kanıtların toplanması; kanıtlar çok kesin de olsa, yanlışlanabilme olasılığının her zaman göz önünde 
tutulması gerekmektedir. Yanlışlama olanağı bulunmayan doğruluğu baştan kabul edilen bilgiler, bilimin konusu olamazlar. Bilimsel yaklaşımın bu özelliği, sosyal bilimlerin katkısıyla toplumsal sorunlarla ilgili gerçeklerin anlaşılmasına ve çözüm üretilebilmesine olanak sağlar.

Sosyal bilimlerin bilime, toplumsal gelişmeye katkısı, bilimsel yöntem ve teknikleri kullanabilmesiyle ilgilidir. Sosyal bilimin bilim olma özelliği de bilimsel yöntem ve teknikleri kullanmasından gelir. Herhangi bir şeyin bilimin konusu olabilmesi için, kanıtlanabilir, üzerinde araştırma yapılabilir, akıl yürütülebilir, en azından yukarıda Popper'ın görüşlerine değinerek de açıklanmaya çalışıldığı gibi, sonsuzca yanlışlanabilir olması gerekir. Sosyal bilimlerin de bilim olma özelliği, burada açıklananlarla paralel bir duruma işaret etmektir. Çünkü sosyal bilimlerin konusu olan insan, üzerinde araştırma yapılmaya elverişli somut bir varlıktır ve sosyal bilim uzmanları da insanların bu özelliğini değerlendirerek bilimsel araştırma yöntem ve tekniklerine uygun çalışmalar yapmaktadır. Sosyal bilimlerde bilimsel araştırma yöntem ve tekniklerinden kasıt ise, Neuman'nın açıkladığı gibi, bilim insanlarının teorileri desteklemek ya da reddetmek için özel teknikler kullanarak veriler toplamasıyla ilgilidir. Sosyal bilimlerde bu veriler nicel, yani sayılarla ifade edilen ya da nitel yani kelimeler, görüntüler, sesler şeklinde olabilir (2007, s. 7). Neuman'ın anlatımından da anlaşılacağ sosyal bilimlerde bilim yapmak için, bilimsel yöntem ve teknikleri bilerek, uygulayarak çalışmalar yapmak gerekmektedir.

"Sosyal bilim" kavramı; konusu toplum olan, insan ilişkilerini, insanı incelemek için var olan araştırma branşları için kullanılan genel bir adlandırmayı içermektedir. Her sosyal bilim, kendisine özgü ontolojik (varlıkbilim), epistemolojik (bilgi felsefesi), yöntemsel ve kavramsal sorunlara sahiptir. Yorum bilim açısından "sosyal olgular", kendi başlarına, anlamlar ya da kurallara bağlı olduklarından, sosyal çalışma ve her sosyal bilim, "kesinlikle" kendi konularının anlamını, açıklığa kavuşturmak ve alana özgü bilgisini geliştirmekle ilgilenmelidir. Örneğin, sosyoloji, antropoloji, psikoloji, sosyal çalışma disiplini gibi sosyal bilimler ile ilgili alanlar, insan, insan davranışlarını, toplumu konu almaktadır ve alan bilgisini de bu yönde geliştirmeye katkı sağlamalıdır.

Yine sosyal bilimlerin, sermaye düzeniyle de yakın ilişkisi bulunmaktadır. Örnek olarak, 
tarihsel süreçte, Fransız devrimi gibi büyük atılımların gerçekleştirilmesinde öncülük rolü oynayan burjuvaziden alınan destekle, sosyal bilimler; toplumsal çalkantıları öngörmek ve kontrol altına alınabilmelerini sağlayacak bilgiye ulaşmak için çalışmalarına devam ederken, üniversiteler, fakülteler ve bölümler şeklinde kurumsallaşıp, devletin ideolojik bir aygıtı olarak işlev görmeye başlamışlardır. 19. yüzyıl başlarından itibaren, sosyal bilimler, Avrupa'daki üniversite sistemi içerisinde kendine kurumsal anlamda yer bulmaya ve kendi konumunu sağlamlaştırmaya başlamıştır (Stremlin, 2007: 17-49).

Sosyal bilimlerin gelişiminde, ulus-devlet ve aynı bağlamda devletin kendisi arasında güçlü bir bağ bulunmaktadır. Bu anlamda sosyal bilimler, ulus devletlerin uyumlu ve uysal bir şekilde devam etmelerini desteklemek amacıyla örgütlenmiştir. Ancak vurgulamak gerekir ki, Wallerstein'in açıkladığı gibi, (2007: 263-265), pozitif bilimlerin aksine, sosyal bilimlerin "nesneleri", kesin bir şekilde öngörülebilir değildir. Dolayısıyla, ulus-devlet ideolojisi sosyal bilimleri kontrol altına almaya çalışsa da, her senaryoda beklentilerin gerçekleşmesi olanaklı olamamıştır ve aslında söz konusu durum da bilimin gelişmesi için en önemli ilkelerden “bağımlı olmama" ilkesiyle uyumludur. Sosyal bilimlerin toplumsal ekonomik gelişmeye katkısının olabilmesi için bilimin bağımlı olmama ilkesinin desteklenmesinin önemi ortadadır.

Bu bakış açısıyla "sosyal bilimler"; toplumsal araştırmalara yoğunlaşan, insan ve toplumla ilgili üretilen tüm bilgiyi, insanı odağına alarak geliştirmeye çalışan bilim dallarının genel adı olarak değerlendirilebilir. Aynı kapsamda "Sosyoloji" ise, insan ilişkileriyle, bu ilişkilerin ortaya çıkışıyla, toplumsal değişme ve gelişmelerle ilgilenen bilim dalıdır. Örneğin, "insanlar, birbirlerini nasıl etkilemektedirler? Davranışları, duygu ve hareket biçimleri nelerdir?" Sosyoloji; insanla ilgili diğer bir bilim dalı olan psikolojiden farklı olarak, bireyin sorunlarına, duygu durum bozukluklarına vb. odaklanarak incelemelerde bulunmaz. Daha çok "insanlar arasındaki sosyal ilişkilerin yapısı" üzerinedir ve bu ilişkilerin nasıl gerçekleştiği, nasıl değiştiği, farklılıkları nelerin tetiklediğiyle ilgilenir. Sosyoloji bu yaklaşımıyla, "insan grubunu” kapsamına alıp, inceler; sosyoloji açısından, grup içinde insanların davranışları, etkileşimleri, ilişkileri öne çıkar. Bu yaklaşımıyla da, örnek olarak, kliklerle, aileyle, dini gruplar ve örgütlenmeleriyle, sapma davranışı gösteren gruplarla, çetelerle, cemaatlerle, makro organizasyonlarla, fabrikalarla, üniversitelerle çalışmalar yaparak, buralardaki insan ve insan etkileşimini içeren her konuda 
incelemeler yapabilir (Macionis, 2008, s. 2-6). Dolayısıyla sosyal bilimlerin işlevine sosyolojik yaklaşımla bakıldığında, sosyoloji, insanın zaman ve yer bağlamında "tek başına olmadığı", her durumda bir grubun, topluluğun içerisinde bulunduğu düşüncesinden yola çıkar. Sosyoloji insan toplumları ve sosyal davranışların sistematik veya bilimsel çalışması olarak da açıklanabilir. Bu açıklamalar, büyük ölçekli kurumlardan ve kitle kültüründen küçük gruplara ve bireyler arasındaki ilişkilere kadar toplumun yapısı dâhilindeki hemen hemen her şeyi içine alabilir (Ferris \& Stein, 2018, ss. 9, 10).

Yukarıda açıklanan sosyoloji bilimi kapsamında sosyologlar (toplum bilimciler); toplumla, toplumla ilgili kurumlarla, insan ilişkileriyle ilgili çalışan meslek elemanlarıdır. Sosyoloji disiplinin öne çıkardığı yaklaşım ise, toplumsal hayatın şekillendirildiği, topluma ait ideallerin, değerlerin öğrenildiği, paylaşıldığı bakış açısına dayanmaktadır (Özkalp, 2011: 2-3). Anlaşılacağı üzere, sosyolojik yaklaşım sosyal bilimlerle ilgili tüm bilim dallarına, insanı ve toplumu içine alması açısından bir bakış açısı sağlamaktadır. Söz konusu bakış açısı ise, sosyal bilimlerin tüm dallarının katkısıyla, demokrasilerin gelişmesi, bilimsel yaklaşımların toplumda değer görüp yaygınlaşması, daha adil sosyoekonomik yaşam koşulları, kültürel farklılıklara saygı gibi birçok konuya umutla bakılmasına yardımcı olmaktadır. Yine toplumu oluşturan bireyler, sosyal bilimlerden yeterli şekilde beslendiğinde, diğer insanlara, doğal çevreye, tüm canlılara karşı daha duyarlı bireyler olabilmektedir.

Buraya kadar gelinen aşamada ise önemli bir konu, sosyal bilimlerin sorunlarıyla ilgilidir. Sosyal bilimlerin fizik bilimlerle karşılaştırıldığında önemli bir farklılığı, fizik bilimlerde somut olarak ortaya konan hipotez testleri, deneylerle kanıtların üretilebilmesi olanaklı olduğu halde, sosyal bilimlerin konusu olan insan ve toplumlar karmaşık bir yapıya sahip olduğundan aynı kesinlikte sonuçlar alınamamaktadır. Bu durumda beraberinde karmaşayı, tartışmaları, getirmektedir. Sosyal bilimlerin yaklaşımları, yöntemleri, kuramlarıyla ilgili söz konusu karmaşık durumla ilgili "Sosyal Bilimlerin Yeniden Yapılanması için Gulbenkian Komisyonu, 1993 Temmuzu'nda, Prof. Wallerstein'in başkanlığında" "altısı sosyal bilimci, ikisi doğa bilimci, ikisi de insan bilimleri dalından" uluslararası çok ileri seviyede akademik bir grupla çalışmalarına başlamıştır (Gulbenkian Komisyonu, 2003). Aşağıda bu komisyonun yaptığı çalışmalarla ilgili verilen bilgi, sosyal 
bilimlerin toplumsal gelişmelere yaklaşımının ve katkısının değerlendirilmesinde katkı sağlayacaktır.

"Sosyal bilimler", Batı dünyasının toplumsal dönüşümündeki "engellerin ve ortaya çıkan sorunların" bertaraf edilebilmesi, ortadan kaldırılması amacıyla sistemleştirilmiş ve büyük ölçüde, politik güçlerin gereksinimlerine yanıt verebilecek biçimde örgütlenmiştir. Feodal düzenin, Ortaçağ'ın, karanlık dönemlerine ait ölü toprağını üstünden atabilmesi için ve dünyayı keşfederek ele geçirebilmesi için, Batı'nın bu büyük adımları atabilmesi, önemli bir "yeniden organizasyona girişmesi" gerekliydi. Bu organizasyona ait ilk adımlarından biri, feodal toplum yapısının, daha merkezileşmeyi öne çıkaran, ekonomik yapılı bir birime dönüştürülmesi olmuştur (Gulbenkian Komisyonu, 2003: 14). İlgili süreç, sosyal bilimlerin büyük doğum sancılarıyla geçmiştir. Feodal dönem geride kalırken, yönetsel anlamda bir merkezileşme, küçük tüccarların büyük ticaret örgütlenmeleri haline gelmesi, bir savaş ve kolonileştirme örgütlenmesinin, yeni şekillenmekte olan ulus devletlerin himayesi altında yükselişi göze çarpmaktadır. Burada da açıklanan toplumsal değişimler, sosyal bilimlerde yaşanan karmaşa, insan bilimlerinin doğasından kaynaklanan sorunlar, sosyal bilimlerin yeniden yapılandırılması gerekliliğini ortaya çıkarmıştır. Gulbenkian Komisyonu anlatılan tartışmalar bağlamında, sosyal bilimlerin aşağıda yer alan özelliklerini vurgulamıştır.

Günümüzde, Anglo-Amerikan denilen kültür dünyasında, "yeni bilim paradigması" başlığı öne çıkarılarak, sosyal bilimlerin şu özellikleri içerdiği vurgulanmıştır: “(1) Gerçeklik karmaşıktır; onda çeşitlilik, karşılıklı etkileşim, özgüllük ağır basar.” “(2) Gerçeklik, hiyerarşik değil heterarşiktir; onda birbirine bağlı olmayan, birden fazla düzen olabilir." "(3) Gerçekliğin, holistik veharmonik bir yapısı yoktur.” “(4) Gerçekliğe mekanizm hâkim değildir; o mekanik bir bütünlük halinde ele alınmaz." “(5) Gelecek belirsizdir; dolayısıyla bilim, önceden bilme (prognos), önceden söyleme (prediction) olanağına sahip değildir.” “(6) Doğrudan nedensellik, yani her nedenin bir sonuç doğurduğunu ifade eden türden, tek yönlü bir nedensellik bulunmayıp, sadece karşılıklı etkileşim vardır.” “(7) Gözlemci, belli bir perspektife sahiptir; dolayısıyla o incelediği olaya veya olguya fiilen katılır; gözlemciyi, gözlenenden ayıran bir mesafe yoktur." “(8) Buna bağlı olarak, "nesnellik” diye bir şey de yoktur; sadece perspektifbağımlı olarak, nesneler hakkında söz etme vardır ki bir şey, ona bakılan yerden görüldüğü 
biçimiyle bilinir." “(9) Tümel/mükemmel bilgi yoktur.” “(10) Tek bir doğru(luk) yoktur.” “(11) Özne-merkezcilik terk edilmelidir; çünkü öznenin kendisi, esasında özneler arası bir ortamda var olabilir.” “(12) Bilgi, gerçekliğe tekabül eden, öznenin bireysel çabasıyla ortaya çıkarılan bir şey değildir; o, özneler arasılık ortamında, birlikte oluşturulan ve tarihsel olarak hep değişen bir şeydir." "(13) Tarih ve toplum dünyasında, bağımsız değişken yoktur; her şey birbirine bağımlıdır ve tüm değişkenler bağımlıdır.” “(14) Sosyal hayatın bilgisi, zorunlu olarak özneler arasıdır.” “(15) Sosyal hayatın bilgisi, belirtilen tüm bu hususlara bağlı olarak, ancak ve sadece yorumdan ibarettir" (Gulbenkian Komisyonu, 2003: 61). Burada açıklanan maddeler, sosyal bilimlerin toplumsal işlevinin yerine getirilmesinde sağlam bir duruş için açınım sağlaması açısından değerlidir. Ayrıca yine insanla ilgili bilimlerin topluma, bilim dünyasına katkısı açısından fizik bilimlerdeki kadar net sonuçlar elde edilememesi, sosyal bilimlerin kendine özgü yöntem ve tekniklerden faydalanılmasına engel olmamaktadır. Gulbenkian Komisyonu gibi bilimsel kuruluşların, ekiplerin yaptığı/ yapacağı çalışmalar toplumsal gelişmeye olabilecek katkıları artırma kapasitesine sahip olmaktadır.

Buradaki bölümde, yukarıdaki paragraflarda açıklanmaya çalışıldığı gibi, bilimin konusu içinde olanlar ve olmayanlar, sosyal bilimlerin konuları, özellikleri, işlevleri, yaklaşımları kısaca değerlendirildi. Anlaşılacağı üzere, sağlam temellere oturmuş sosyal bilimler, sosyo-ekonomik gelişim için, ayrıca toplumun bireylerinin gelişmesine katkı sağlanabilmesi açısından zorunludur. Bilimin gelişebilmesi için öncelikle, yetkin bir bilimsel yöntem bilgisiyle, bilimsel yöntemin doğru olarak konumlandırılması gerekmektedir. Bilimsel yöntem doğru olarak konumlandırıldığında, sosyal bilimler de doğru bir yaklaşıma sahip olacaktır. Doğru bir sosyal bilim yaklaşımı ise, soran, sorgulayan, araştıran, bilimin önemini, değerini kavrayan, öğrenme aşkıyla donanmış bireyler yetiştirilmesine katkı verecektir. Bireylerin bu şekilde sosyal bilimlerin katkısıyla donanımlı olması ise, fizik bilimlere ilgi duyan insanların da çoğalmasına, dolayısıyla teknolojinin gelişmesine, yüksek teknoloji ürünlerinin üretilmesine katkı sağlayacaktır. Aynı zamanda toplumsal barışın, adaletin, dayanışmanın kendi kaderini kendisi gerçekleştiren, demokrasiyi tüm nimetleriyle işletebilen bir toplumun kurulması da sosyal bilimlerin katkısıyla olanaklı olabilecektir.

\section{Bazı Önemli Teorisyenlerin Yaklaşımları Açısından Toplumsal Gelişme}


Bilindiği gibi, kısaca açıklanırsa Rönesans ile birlikte, edebiyata, sanata, tarihe, felsefeye ve diğer tüm bilim dallarına ilgi artmış ve özellikle Avrupa coğrafyasından başlayarak bilgiyi, bilimi hayatlarının merkezine alan insanların sayısı hızla çoğalmıştır. Reformasyon hareketi ile birlikte başlayan süreçle ise, kilisenin bilime, bilimsel uyanışa koyduğu engeller sonlandırılmış, din bireye ve bireysel inanca evrilmiştir. İnsanlık bundan sonra, Fransız devrimi, Endüstri devrimi gibi önemli gelişmelere tanık olmuş, her işlerinde, her konuda bilimi merkeze alan devletler hızla gelişmiştir. Söz konusu gelişmelerde ise, her devrin değerli sosyal bilim uzmanlarının etkisi yadsınamaz. Aşağıdaki satırlarda, sosyal bilimler tarihine imzalarını atmış önemli sosyal bilimcilerden bazı örneklerle, toplumsal gelişmelere katkıları açıklanmaya çalışılacaktır.

Saint Simon (1760-1825), ilk önemli sosyologlardan kabul edilmektedir. Onun sosyal bilimlerin hemen hemen tüm dallarıla ilgilendiği görülmektedir. Fizik bilimlerden yola çıkarak ise, bu bilimlerin benzer şekilde "pozitif bir sosyal bilim"in ortaya çıkarılmasıyla tamamlanabileceğine inanmıştır. Bu düşünncelerden yola çıkarak yeni bilime "sosyal fizik" demiştir. Simon'a göre fizik bilimlerin fiziksel olayları açılaması, kontrol edebilmesi gibi, sosyal fizik de toplumsal durumları, sorunları önce fark edebilir. Sosyal olayları kontrol altına alabilir, şekillendirebilir (Durkheim vd., 2010, s. 62; Bhushan, 2016, s. 73,74). Simon, yaptığ1 çalışmalarda sosyolojisini öncelikle teorik olarak inşa edip, daha sonra uygulanmasını düşünmüştür. Birçok sosyolog gibi yaşadığı dönemin sorunlarına odaklanarak, toplumdaki düzensizliklere, krizlere çözüm bulma amacını gütmüştür. Bu yolla sosyolojinin gücüne inandığı için, adeta sosyolojinin yeni bir din haline dönüştürülmesini ve toplumu örgütlemesini düşünmüştür. Yaşadığı toplumu gözlemleyen Simon endüstrileşmenin toplumda yarattığı değişiklikleri iyi gözlemleyerek, feodalizm ve onunla birlikte var olan hiyerarşik yapıların geçerliliğini yitirdiğini, tarımsal üretimin en önemli üretim ve gelir kaynağı olmaktan çıktığını fark etmiştir (Musso, 2017). Simon'un bu yaklaşımında da görüldüğü, sosyoloji ve diğer toplum bilimlere düşen önemli görev, toplumsal değişimlerin, gelişmelerin, sorunların farkına vararak, öngörülü hareket ederek olası çözümlere katkı sağlamaktır.

Toplumsal gelişmelerin takibinde endüstri devrimi sonrası insan hayatında olan 
değişimler, sadece üretimde bir değişikliğe sebep olmamış, aile, kültür, siyaset vb. akla gelen her şeyi değiştirmiştir. Simon da gözlemlerine dayanarak, sanayi üretimiyle ilgili değişimlerin tüm yaşamsal koşulların değişimine etki ettiğini açıklamıştır. Ayrıca, zamanının İngiliz ekonomistlerinin de etkisiyle, sosyal düzenin temelinde ekonomik yapı olduğu görüşünü savunmuştur. Bu yaklaşımıyla, insan tarihinin gelişiminde düşünüş biçimlerinin yanında, üretim şeklinin nasıl olduğunu, servet paylaşımının sınıf tabakalaşmasına etkisinin nasıl gerçekleştiğini anlatmaya çalışmıştır. Yine Simon devletin görevinin toplum için faydalı işlerin gerçekleşmesini sağlamak olduğunu anlatır. Halkın isteklerinin dikkate alınması gerektiğini, üretim için en önemli güç olan çalışanların değerinin bilinmesi gerektiğini açıklar. (Musso, 2017).

Sosyal bilimlerde çok önemli bir yeri olan diğer bir düşünür de, aynı zamanda sosyolojinin de isim babası olan Auguste Comte'dur (1798-1857). Büyük ölçüde Simon'un görüşlerini benimsemiş, toplumun da diğer bilim dallarında olduğu gibi, "gözlem, karşılaştırma ve deney"le incelenebileceğini savunmuştur. Ona göre toplum gerçekliğini oluşturan, onu açıklayan sosyolojik yasalardır. Toplumların gelişmesini harekete geçiren ise, "insan düşüncesidir." Toplumların tarihine de dikkat çekerek, en dikkate değer teorisi, insanlığın tarihsel süreçteki geçirdiği aşamalarla ilgili olan, "üç hal aşaması"dır. Bunlar “teolojik dönem, metafizik dönem ve pozitif dönem" olarak bilinmektedir. Kısaca açılanırsa, “Teolojik" ve "metafizik" dönemlerde, evrendeki her şeyin, "teolojik-metafizik" düşüncelerle anlatımı yapılmaktadır. "Bilimsel dönem" olarak da anlaşılan "pozitif" aşamada ise, endüstrileşmenin, bilimin, aydınlanma düşüncesinin geliştiği bir dönemin de etkisiyle, olgular, olgularla açıklanmaya başlanmıştır. Diğer taraftan da, toplumsal gerçekliğin, diğer doğal olaylardan çok daha karmaşık bir bütün oluşturduğunu dile getirerek, sayısal açıklamaların, tek başına yetersizliğini savunmuş, böylece geleneksel bazı tehlikeleri önceden gösterebilmiştir (Aron, 2014, ss. 61-64).

Yine en önemli düşünürlerden Hegel (1770- 1831); “diyalektik” kavramını ilk kez kullanarak bunun "bir karşılıklı ilişkiler olgusunu ya da etki-tepki sürecini içerdiğini; evrendeki her şeyin her nesnenin, kendi bünyesinde karşıtını ve çelişkisini içerdiğini, bu nedenle de her nesnenin, kendisiyle çatışma ve çelişki halinde bulunduğunu" ifade etmiştir. 
Her varlık, kendi bünyesinde barındırdığı karşıtlar sayesinde kendini aşma, yeni bir yapıya kavuşma olanağı bulur. Hegel için, "varlığın temelinde, düşünce” yatmaktadır (2018, s. 66).

Sosyal bilimler tarihinde çok önemli bir yeri olan Karl Marx (1818-1883), materyalist bakış açısıyla, düşüncenin maddeden, evrensel ilkenin doğadan ürediğini ileri sürerek maddeci diyalektiği savunmuştur. Ona göre toplum, paylaşılan idealler, fikirler tarafından yönetilmez. Toplumlar, güce, zenginliğe sahip insanlar tarafından yönetilir. Böylece gücü kendi çıkarlarına kullananlarla, bu durumdan zarar gören diğerleri arasında çatışma kaçınılmaz olur. Bir taraftan iktidar, güç, zenginlik sahipleri, kendileri için çalışanlara daha az olanak tanıyarak kendi güçlerini artırmak isterken, çalışanlar ve yoksul durumda olanlar ise, daha iyi koşullarda yaşamak için mücadele ederler, bu da çatışmayı kaçınılmaz hale getirir. Böylece, üretim araçlarına (toprak, emek, sermaye) sahip olanlarla (yani burjuvazi); olmayanlar (yani işçi sınıfı) arasında, sürgit bir çatışma söz konusu olacaktır. Marx’a göre toplum, düzenli bir yapı olmayıp; çelişme yasasına göre, düzen düzensizliğe, durağanlık da çatışmaya gebedir. Toplumun devamlılığı "üretime", üretim de toplumun temel yapısı olan "altyapı"ya bağlıdır. Üstyapı kurumları olan; hukuk, gelenek, görenek, din ve inançlar, felsefe, bu altyapı üzerine kurulmakta ve onun tarafından biçimlendirilmektedir. Onun düşüncelerinde, modern sosyal çalışma şekline altyapı sağlayan unsurlar da bulunmakta olup, kapitalist bir toplumda, "en geniş sosyal refah olanakları yaratılmasında" itici bir güç oluşturmuştur. Marx’ın, kapitalist toplumlarda, ezilen ve yoksullaşan kesimlerin sayısı arttığı takdirde, kaçınılmaz biçimde çatışma yaşanacağı öngörüsü; sosyal çalışma ve sosyal refah sistemlerinin, Batı dünyasında etkili biçimde aktive edilmesine ve mağdur kitlelere gelir transferi yoluyla, "sosyal çatışmaların” en aza indirilmesi düşüncesine kaynaklık etmiştir (Elster, 1986, ss. 112-116).

Herbert Spencer (1820-1903), ise, Darvin'in biyolojik evrim kuramıyla ilgili yapmış olduğu çalışmalara, toplumların geçirdiği evrimle ilgili açınımlar kazandırmıştır. Böylece onun kuramının toplumu anlama, araştırma açısından da yansımaları olmuştur. Nasıl ki canlılar dünyasında “ortama en uygun olan ve uyum sağlayanlar, yaşamlarını sürdürebiliyorsa" toplumsal yaşamda da aynı durum söz konusudur (Turner, 1999, s. 278). Benzer yaklaşım sosyal bilimler ve ilgili farklı teoriler tarafından destek bulabildiği gibi, karşıt yaklaşımlar da ileri sürülmektedir. Örnek olarak sosyal çalışma disiplini, Sosyal Darwinizmin 
tersine, en güçlü olanların, rekabet edebilenlerin yaşayabileceği düşüncesini reddeder. Yine sosyal çalışma yaklaşımı devletlerin, zor durumda olan, yoksul olan vatandaşlarına karşı sorumluluğu olduğunu vurgular (Yolcuoğlu, 2019, s. 59). Yani bu yaklaşımıyla sosyal çalışma disiplini, insanın insan olmasından doğan farklılığa, vicdana, duyarlılığa işaret ederek, doğan her insanının "insana yakışır" şekilde yaşama hakkına işaret eder.

Sosyolojinin kurucuları arasında sayılan Emile Durkheim (1858-1917), “Toplumu bir arada tutan unsurlar nelerdir?" sorusunu cevaplamaya çalışmıştır. Verdiği cevapta da dayanışmanın, bir arada kalmanın, insanların fikirler ortaya çıkarmasıyla, doktrinlerle, inançlarla, doğmalarla, değerlerle, kurallarla sağladığını anlatmıştır. Yani, toplumsal gerçekliğin temellerini; bir toplumun bireylerinin sahip olduğu ortak inanç, değer, düşünce ve duygular bütünü olan, "toplumsal bilinç" oluşturmaktadır. Durkheim’e göre, "sosyal düzen", toplumdaki semboller tarafından yürütülür ve semboller zamanla, birey kişiliğinin bir parçası haline gelir. Karmaşık ilişkiler de, yine tarafların aralarında geliştirdikleri görüşmelerle sürdürülür. Ayrıca, yaptığı araştırma çalışmalarıyla güçlü sosyal bağlar kurabilmiş, toplumla bütünleşme sağlayabilmiş insanlarda, yabancılaşma ve intihar oranlarının düşük olduğunu bulmuştur. Durkheim; toplumda birilerinin öldüğünü, diğerlerinin doğduğunu, toplumun, dil, yazı, yasalar, gelenekler, dinsel gruplar, mülkiyet, aileler, sanat, mimarlık, kültürler, tarih ve kimlik duygusu gibi unsurlarla birlikte devam ettiğini; bir futbol takımındaki yüksek yetenekli oyuncular gibi, yüksek donanımlı bireylerin sosyal yaşamda fark yaratarak olayların ve toplumun seyrini değiştirebildiklerini ifade etmiştir (Smart ve Ritzer, 2001, ss. 83-86).

Max Weber ise (1864-1920); “toplumsal değişime” önemli katkılar sağlamış, ayrıca, toplumsal tabakalaşma, din, bürokrasi gibi konularda önemli eserler gerçekleştirmiştir. Özellikle de dinin kapitalizmin gelişmesi, toplumsal değişimlerdeki etkisi üzerine, bürokrasinin nasıl işlediği üzerine çalışmalar yapmıştır. Bireylerin toplumsal eylemleri ve bunların içerdiği anlam nelerin üzerine kurulmaktadır gibi sorular sormuş ve toplumsal davranışların "iç anlamlarını", "kültürel anlam ve değerlere” bağlamıştır. O, "insanlar için dünya ne anlam taşımaktadır; insanlar dünyayı nasıl tanımlamaktadır" sorularıyla da, "evrenin ve yaşamın anlamı üzerinde" durarak, "yorumlu anlamanın” (hermeneuetik) 
önemini vurgulamıştır (Bhushan, 2016, ss. 85-91).

Weber'e göre; toplumlar modern öncesinden modern devlet olgusuna geçerlerken, rasyonel düşünce ve örgütlenme biçimlerinin karakteristiklerini giderek daha çok etkili kılmaya başlamışlardır. Kapitalist gelişme; özgül pratik amaçlarına erişebilmek için; rasyonel yönetim, rasyonel muhasebe, bilim, hukuk vb. enstrümanları aracılığıyla kamusal düzenlemelerin sistematik bir biçimde uygulanmasına dayanmaktadır. Rasyonalizmin bir yönü olarak "bilimsel bilginin" yasal-rasyonel otoritenin önemli bir bileşeni ve dayanağ1 olduğunu, bu rasyonellik aşındırıldığı takdirde, bunun toplumdaki iktidar yapısının meşruiyeti ve bireylerin toplum içerisinde seçtikleri tutum, davranışlarında köklü değişikliklere neden olacağını öne sürmüştür (Brubaker, 2006). Ayrıca güç ve otoritenin toplumdaki etkisi üzerinde durmuş, politik otorite, yasal rasyonel otorite, geleneksel otorite, karizmatik otorite ayrımı yaparak, güç ve iktidar ilişkileri açısından açıklamalarda bulunmuştur (Tischler, 2011, s. 344).

Günümüze doğru yaklaştığımızda, Talcott Parsons (1902-1979), “yapısal-işlevsel yaklaşım”ı önemli teorisyeni olarak; toplumsal sistem üzerinde durmuş, "ekonomi”, "din”, “aile", "politika", “eğitim" gibi kurumların, toplumdaki görevlerinin ve işlevlerinin, toplumdaki yerini vurgulamıştır. Ona göre toplumu bir arada tutan, bireylerin, grupların arasında bulunan karşılıklı etkileşimdir. Bütün ve parçalar arasında var olan ilişkiler, “toplumsal sistemin temelini" oluşturmaktadır. Parsons'la birlikte, yapısal işlevselcilik genel olarak, Spencer, Durkheim, Merton'a atıfla da anılmaktadır. Yine genel bir değerlendirmeyle, işlevselcilik, toplumu birbiriyle uyumlu yapılar ya da uyumlu bir şekilde işlev gören ya da birlikte çalışan parçalar sistemi olarak görür. İşlevsel yaklaşım, "toplumu”, dengeye ulaşma çabası içerisinde olan bir sistem olarak görmektedir. Aynı paralelde işlevselciler de toplumu analiz ederken, toplumda var olan her bir farklı parçanın bütünün düzgün işleyişine nasıl etki ettiğini sorarak anlamaya çalışırlar. Örnek olarak eğitim sistemi, topluma uyum ve toplum için gerekli görevlerin yerine getirilmesi için öğretme faaliyetleri için bulunur. İşlevselcilere göre, toplum oldukça istikrarlı bir şekilde kendi kendini düzenler görünmektedir. Biyolojik organizmalar nasıl doğal durumlarda denge halindeyse, toplumda benzer şekilde bir denge halindedir. Toplumların üyelerinin çoğu ortak bir değerler sistemini paylaşır ve birbirlerinden ne bekleyebileceklerini 
bilirler (Tischler, 2011, s. 19). Anlaşılacağı gibi, toplumda da doğal bir denge vardır. Her şey olması gerektiği gibi olmaktadır. Ancak tahmin edilebileceği işlevselcilik de diğer teoriler gibi, eleştiriye açıtır ve eleştirilmiştir.

Yukarıdaki paragraflarda bazı önemli sosyal bilimcilerin görüşleriyle ilgili açıklamalarda bulunularak, toplumların, insan doğasının analizinde, sosyal bilimlerin önemine dikkat çekilmek istenmiştir. Kuşkusuz burada sosyal bilimlere emek ve çok değerli katkılar sunmuş, çok az bilim insanının çok sınırlı görüşlerine yer verilmiştir. İnsan bilimin nesnesi olduğunda, fizik bilimlerdeki kadar somut kanıtlar bulup, toplumu ve insanı açıklamak olanaklı olmamaktadır. Ancak yukarıda fikirlerine yer verilen sosyal bilimcilerin görüşleri de genel olarak değerlendirildiğinde de anlaşılacağı gibi, içinde yaşanılan toplumu ve insanı anlayabilmek, toplumsal, insansal sorunları analiz edip, çözüm yollarıyla ilgili fikirler üretilebilmesine katkı sağlayabilmek için, sosyal bilimlere, bu alanda çalışma hedefi olan bilim insanlarına ihtiyaç bulunmaktadır. Doğada ve toplumda sürekli bir değişim kaçınılmaz olarak devam etmekte, her değişim ise, tek tek insanların, toplumların uyumunu zorunlu hale getirmektedir. Böyle olunca, tarihte yerini almış düşünürlerin yanında, yeni koşullara göre yeni bakış açıları, teoriler geliştirmeye katkı yapabilecek düşünürlere ihtiyaç bulunmaktadır. Bu bölümde yer verilen bazı düşünürlerin, sosyologların teorilerinde de görüldüğü gibi, gerçeklik bakış açısına göre değişebilmekte; her teorinin eleştirildiği tarafları olduğu gibi, bilime, toplumsal gelişmelere katkı sağlama açısından kullanışlı tarafları da bulunmaktadır. Burada sosyal bilimlerde uğraş verenlere düşen görev ise, alandaki teorilere, araştırmalara mümkün olduğu kadar hâkim olup bilimi daha üst seviyelere taşıma olmalıdır.

\section{SOSYAL BILIMLERIN TOPLUMDAKİ İŞLEVI}

"Bilim", "sistematik bilgiler" bütünü olarak, bilgileri, olayları titizlikle gözleyerek, ölçerek, bilim insanlarının düzenledikleri deneyler aracılığıyla toplar. Gözlenen olaylar, betimleyici (descriptive) ve yordayıcı (predictive) nitelikli genel yasaların veya ilkelerin ortaya konulmasıyla, bu sistematik olma özelliğine kavuşabilmektedir (Aziz, 2017: 40). Bu özellikleriyle, sosyal çalışma da hem bir bilim dalı, hem meslek, hem de sanattır. Bilindiği gibi "sanat", bilimle karşılaştırıldı̆̆ında, bireyin kendisini ifadesinin, toplumsallaşmasının da bir aracı olarak, 
eğitimle, uygulamalarla yaşantıyla elde edilen bir beceri, farklılık ortaya koyabilmeyle ayrilmaktadir.

Bir konunun "bilimselliği”, genellikle sistematik bir bilgi gövdesi yaratarak, belli yasalara ulaşabilmesi ve bunu yaparken de, gözlem, varsayım, test ve genellemeler gibi “bilimsel yöntemleri" kullanması ölçütlerine bağlıdır. Esasında bu yöntem, klasik "ispat" mantığına dayanmakta ve "yadsıma" ya da "kabul", bir bilginin gerçeğe uygunluğu açısından "denenmesine" bağli bulunmaktadır (Aziz, 2017: 53).

Sosyal bilimlerde insanı ve toplumu anlama; önceki bölümde tarihsel süreçte yer almış birçok düşünürden de örneklerle açıklanmaya çalışıldığı gibi, birçok farklı bakış açısıyla, yaklaşımla değerlendirilmektedir. Ancak bu durum, sosyal bilimlerin de, doğa bilimleri gibi bilimsel yöntemleri etkili bir biçimde kullanarak, sistemli, geçerli bilgiler üretebilmesine engel değildir. Bilimin amacı, doğa bilimlerinde, doğayla ilgili gerçekliklere ve olgulara ilişkin, işleyiş kurallarını keşfedebilmek olduğundan; sosyal bilimlerde de amaç toplumsal gerçeklikleri ve bunların etkileşim mekanizmaların bulmaktır. Bilimsel yöntem, bu amaçlara ulaşabilmek için, düzenli, sistematik bir yol izleyerek gerçeğe en uygun "bilgi üretme” çabasıdır. Bu yöntemin temelini, eldeki verilerin gerçeğe uygun olup olmadığını irdelemek, varsayımlar ve kurallar oluşturarak, "işleyiş kanunlarına” ulaşabilmek oluşturmaktadır.

Doğa bilimleri, doğanın işleyişine hâkim olan kanunları bulmak, bunları insanlığın uygarlığın gelişimi için kullanmak amacındadır. İnsanoğlu bu yolu izleyerek teknoloji sayesinde daha konforlu bir hayat kurabilmiştir. Macionis' in de genel olarak değerlendirdiği gibi, sosyal bilimler toplumsal dünyayı anlama açısından bir pencere, perspektif açmakta, toplumların doğuş, işleyiş ve yok oluş kanunlarına ulaşmaya çalışmaktadır. Toplum bilimlerine ilişkin bilgiler güçlendikçe, insanoğlu, her zaman kaderin, koşulların kurbanı olmadığını, toplumun ve toplumsal yaşamın, insan eliyle yapılandırılabileceğini fark etmiştir (2018, s. 30-40). Bu bilgiler, toplumsal gerçekliklerin yasalarına göre, arzu edilen toplumsal ve siyasal sistemi daha kolay değiştirebilme, dönüştürebilme yetisi sağlamıştır. Toplumsal bilimler, sosyal, kültürel olay, varlık ve bunlara özgü kanunlarla sınırlı olduğundan, toplumu ancak, mevcut gerçekliğin işleyiş kanunları çerçevesinde etkileyebilirler. (Örnek olarak doğa bilimlerine ilişkin bilgiyle, insan uçabilmek için, yer çekimi kanununu bulmuş ve yer çekimini yenecek kapasitede araçlar 
geliştirerek uçulabileceğini öğrenmiştir).

Sosyal bilimlerin toplumdaki işlevini değerlendirme anlamında en önemli görevlerden birisi de, insan toplumlarının kuruluş, işleyiş, kendisini yeniden üretme, yaratma mekanizmalarının incelenmesi, anlaşılması ve açıklanmasıyla uğraşan bir sosyal bilim dalı olarak sosyoloji bilimine düşmektedir. "İnsanların her zaman öteki insanlarla birlikte, onlarla iletişim içinde, alışveriş, rekabet ve işbirliği halinde, yaşamak zorunda olmalarının anlamı nedir?" diye soran Bauman; sosyolojinin bize, kendi bireysel yaşam deneyimlerimizle, daha geniş toplumsal sistemler arasındaki ilişki ve bağlantıları görebilmeyi öğretmesi üzerinde durmaktadır. Sosyolojik bilginin yapısını oluşturan şeyler, sıradan insanların sıradan günlük yaşam deneyimleridir. Ayrıca, ona göre, başka insanlarla birlikte yaşamak için, adına temelde sağduyu diyebileceğimiz çok sayıda bilgiye gereksinimimiz var. Böylelikle, sosyolojik düşünen biri, insanların birbirleriyle kurdukları bağlardan oluşan çok katmanlı ağları araştırarak, insanı anlamlandırmaya çalışır (2014: 37).

İnsan sosyal varlık olarak tanımlandığında, bir toplum içerisinde ve ancak diğer insanlarla birlikte yaşamını doğasına uygun biçimde sürdürebilmektedir. Bu çerçevede "sosyalizasyon"; bireylerin, öz kapasitelerini geliştirdikleri, toplumsal kültürü öğrendikleri, hayat boyu süren sosyal deneyim süreçleridir. Sosyal deneyimleri yaşayan bireyler, tutarlı davranma, düşünme, sosyal olma, diğerleriyle ve toplumla ilgilenmeye yönelik hissetme biçimleri ve davranış repertuarları geliştirirler. Dünyayı acı ve zevk açısından deneyimleyen çocuklar, ahlaksal gelişim açısından "doğruyu", onlara neyin iyi hissettirdiğiyle ölçerek kendi dünyalarını kurmaya başlarlar. Ergenliğe ulaştıklarında ise, ahlaksal yargılara varırken, "niyeti" değerlendirmeye başlayarak, ailelerinin ve toplumun normlarını/kurallarını fark ederek davranış repertuarlarına katarlar. Böylelikle sosyal bilimlerin de üzerinde durduğu "sosyalizasyon" insanların toplum halinde yaşamasını olanaklı hale getirmiş olur.

Yine sosyal bilimlerin toplumsal açıdan işlevini Giddens da sosyolojik açıdan değerlendirirken, "sosyoloji, insanın toplum yaşamının, insan grupları ile toplumlarının bilimsel incelemesidir" demektedir. Ona göre, sokaktaki insanların sıradan davranışlarından terör olaylarına kadar analiz etmeye çalışmak, sosyolojinin görevidir. Örnek olarak, bir kahve 
içme faaliyeti, kişinin kendisini iyi hissetmesi, bağımlılık ve uykusuzluğa yol açması yönüyle psikolojinin, tıp biliminin alanına girmektedir. Ancak, kahve ayrıca, bir sosyalleşme aracıdır. Kahveyi üreten Güney Amerikalı, Afrikalı işçiler, onların yaşam koşulları, uluslararası ticaret, kapitalizm, azgelişme, küreselleşme dikkate alındığında tüm bunları anlamak için sosyolojiye ihtiyaç duyulur (Giddens, 2012, ss. 38-41). Burada da görüldüğü gibi, "sosyoloji”; toplumların nasıl işlediğini ve insanların, nasıl algıladığını, toplumsal gerçekliğin nasıl cereyan ettiğini anlamaya çalışmaktadır.

Sosyal bilimlerin toplumsal işlevini değerlendirirken sosyolojik olarak değerlendirilebilecek bir diğer kavram da "toplumsal kurumlar" konusundadır. Toplumsal kurumlar, sosyal çalışma bilimi açısından da büyük bir öneme sahiptir, toplumsal yapı, temel değerler, bunların korunması, sürdürülmesi açısından kuvvetle gerçekleşmesi beklenen, görece süreklileşen kurallar topluluğu olarak sosyal çalışmacılar tarafından dikkate alınmayı gerektirir. Sosyolojide, toplumsal düzeni sağlayan kurumlar, genellikle beş tane olarak kabul edilmektedir ki bunlar, "Aile, siyasal kurumlar, din kurumu, ekonomi kurumu, eğitim kurumu"dur (Aydın, 2000, 20, 21). Toplumun hemen hemen tüm kurumları, gerektiğinde yaşadığımız toplum için fedakârlıkta bulunmamızı ögütler ve "yaşama bir anlam kazandırmaya" çalışır, çünkü yaşam bir yönüyle, hepimizin büyük bir ciddiyetle oynamayı sürdürdügümüz bir oyun-gerçeklik gibidir. "Toplumsal kurumlar" da sosyal normlar tarafından, düzenli ve sürekli olarak yinelenen, meşrulaştırılan, sürdürülen sosyal pratiklerdir.

Sosyal bilimlerin işlevi değerlendirilirken dikkat çekilebilecek bir konu da, ideolojiler ile ilgilidir. Eaglaton'ın açılamasına göre, “İdeolojiler”; sosyal ve politik eylemlerin altında yatan gerçeklik ve topluma ilişkin fikirler, inançlar bütünü olarak, çoğu zaman, güçlü sosyal grupların konumlarını ve çıkarlarını meşrulaştırmak, desteklemek, egemen kılmak için kullanılan kapsamlı paradigmalardır. Bu açıdan ideolojiler egemen sosyal grupların, sınıfın gücünü meşrulaştırmakla ilgidir. Baskın olan güç, kendi çıkarlarına uygun inançları, değerleri, olanaklarıyla destekleyerek kendisini meşrulaştırabilir. Yine kendi çıkarına uyan görüşleri, akılcılaştırma, kaçınılmaz kılma, doğallaştırma, evrenselleştirme yönünde kültürel değerler oluşturabilir. Meydan okuyabilecek fikirlerin ise, aşağılanmasını, gözden düşürülmesini 
sağlamak yoluyla, sosyal gerçekliğin sezdirilmeden gizlenmesini gerçekleştirebilir (Eagleton, 1991, ss. 5, 6). Anlaşılacağı gibi, ideolojiler kolaylıkla, gerçeği aramak yerine, güçlü olanların, egemen sınıfların ya da iktidarların emrine girip belirli çıkarları meşrulaştırmanın aracı olabilir. Görüldüğü üzere güçlü bir sosyal bilim toplumsal hayatta etkili olup halka inmediği sürece, ideolojiler halkın tamamının çıkarını gözetmek yerine sadece egemen olanların çıkarlarını gözetmenin bir aracı olabilir. Aynı zamanda ideolojiler tüm toplumu kimlerin, nasıl yöneteceğine etkisi açısından da son derece önemlidir. Tüm bunlardan da anlaşılacağı gibi, sağlıklı bir toplumda yaşamak için, güçlü, tarafsız, sadece bilimin emrinde olan bir sosyal bilim kurmaya çalışmak yaşamsal bir zorunluluğa sahiptir. Bu amaçla, sosyal bilimlerin tarafsızlık ilkesi korunarak, gerçeği arama ve topluma fayda sağlama yolculuğuna devam edilebilir.

Yine sosyal bilimlerin amaçları doğrultusunda kullanılabilmesi, toplumda yerini bulması açısından önemlidir. Örnek olarak, toplumu ve insan ilişkilerini inceleyen bilim dalları olarak, "psikoloji", insan davranışını anlamaya; "sosyoloji", toplumu ve birey-toplum arasındaki etkileşimleri anlamaya çalışırken, "sosyal çalışma" bir toplumda sağlıklı bir değişmenin ve "insani gelişmenin" nasıl sağlanabileceği, bireylerin iyilik hallerinin nasıl desteklenebileceğine odaklanarak katkı sağlamaya çalışmaktadır (Yolcuoğlu, 2017: 410). Yine "antropoloji” insanın doğada var oluşundan başlayarak, insanların değerleri, inançları ve geleneklerini, kültürlerini inceleyerek zamanımıza gelen süreçte toplumsal kültür birikimimize 1şık tutmakta, çok kültürlülüğe dikkat çekmek yoluyla, farklı kültürlerden insanları anlamamıza, onlara saygı duymamıza katkı yapmakta, dolayısıyla toplumsal ve uluslararası barışa hizmet etmektedir (Haviland vd., 2002, ss. 802-805).

Sosyal bilimler sosyal çalışma özelinde değerlendirildiğinde ise; sosyal adalet düşüncesine ve bireyin iyilik haline odaklanarak, sosyo-ekonomik koşulların yeniden yapılandırılmasına, toplumda yaşayan tüm insanların daha mutlu, sağlıklı olma durumlarının destek bulmasına ve temel ihtiyaçlarının karşılanmasına çalışır. Bakış açısı olarak, bir toplumsal sorun olduğunda değil, toplumsal sorun olmadan önce önlem almaya odaklanır. Örnek verilecek olursa, maddi yetersizlik ve yoksulluk vb. sebeplerle insanların hırsızlık, hayat kadınlığı vb. yanlış yollara yönelmesini, insanlar istenmeyen bu gibi durumlarla 
karşılaşmadan önlemeye çalışır. Bütün bunlara elverecek yasal düzenlemelerin yeterli olmadığı durumlarda, bedenini satan bireyleri suçlayıcı olmaksızın, bu durumun elverişsiz sosyal, ekonomik koşulların nedeni ve istenmeyen durumlar olarak yaşandığı gerçeğiyle, bireyi yalnızlığa ve çaresizliğe terk eden toplumsal sistemi suçlar; sosyal restorasyon yapmak için müracaatçısını kabul eder. Böylesi bireylerin, olumsuz yaşam koşullarından kurtarılması, rehabilite edilmesi ve iyilik halinin desteklenmesi, eğer varsa çocuklarıyla birlikte, toplumun "onurlu bir üyesi olarak" yaşayabilmesi için, gerekli mesleki müdahalelerini hızla gerçekleştirir ve bireylerin yaşamında onarımlar gerçekleştirebilmeyi hedefler (Yolcuoğlu, 2017: 200).

Yine sosyal çalışma bilimi, Parsons'ın görüşlerinde de yer aldığı gibi, belli bir yapıdaki toplumun, kendini oluşturan parçalar olan birey ve grupları etkilemesi üzerine odaklanır. Şöyle ki Parsons'a göre, bir toplumdaki aile yapısı, çocukların eğitimi, politika, sağlık gibi parçalar, toplumsal yapının önemli unsurları olarak, bu yapının devamına katkıda bulunuyorsa o toplum "işlevsel bir toplum" dur. Parsons bir örnekle durumu açıklar: Bütün dinler, genelde aile kurumunu destekleyerek, bir dini törenle evlenmeyi ve evli kalmayı, çocuk sahibi olmayı, çocuklara eğitim verilerek, büyüklere, diğer insanlara saygı, sevgiyle bağlanmayı öğretir. Bunun sonucunda aile üyeleri, dine, geleneklerine bağlı olarak, aile ve din kurumu birbirine işlevsel biçimde bağlanarak, birbirini destekler (Parsons, 2015: 160). Söz konusu yaklaşım, işlevselcilerin, toplumda görevlerin dağılımının olması gerektiği gibi olduğu şeklindeki görüşleri dışında, sosyal çalışmacıların da dikkate aldığı bir durumdur. Aynı şekilde sosyal çalışma da "işlevsel bir topluma", üyelerini geliştiren, sağlıklı değişimi yönetebilen bir toplumsal yapı hedefine ulaşmaya çalışan bir meslek ve disiplindir. Bu anlamda işlev, belirli bir toplum içerisinde, her geleneğin, düşünce, değer ve inancın, birey ve grubun oynadığı rol anlamına gelmektedir.

Toplumsal yaşam, bireylerin toplum içerisinde sürdürdüğü, diğerleriyle kurdukları sözlü ya da sözsüz iletişimden, negatif ya da pozitif ilişkilerden, iyi ya da kötü etkileşimlerden oluşmaktadır. İnsanlar birbirleriyle karşılaşmakta, iletişim veya ilişki kurmakta, hatalar ortaya çıksa da karşılıklı "sosyal etkileşime" dâhil olmaktadır. Her bireyin toplumu etkilediği gibi, toplum da bireyi etkilemektedir. Bu arada toplumsal gelişmenin olumlu ya da olumsuz olması 
açısından önemli bir diğer önemli faktörü ise, toplumsal düzlemi oluşturan iyi ya da kötü, yeterli veya yetersiz olarak, kamu otoriteleri yani devlet tarafından belirlenmiş, normlar ve kurallar belirlemektedir.

Burada önemli bir soru, bütün insani, bireysel, toplumsal ve bireylerarası iletişim ve etkileşimler, "kendiliğinden" bir şekilde cereyan ederken; toplumsal bilimlere neden ihtiyaç duyulduğuyla ilgilidir. Modern dünya, gelişen veya değişen yaşam biçimleri, insan ilişkileri son derece karmaşık ve birbirine bağımlı, karşılıklı olumlu-olumsuz etkileşim içerisinde olduğundan dolayı, bu kaosu anlayabilmek için, açık fikirli olmak, rasyonel düşünmek ve sistematik bilgiler üreterek, bireysel yaşamları da bu "gerçeklikler doğrultusunda" yapılandırmak gerekmektedir. Sosyal bilimler, bu noktada büyük önem kazanmakta olup, rasyonel kanıtlar ve ispatlarla oluşturulan bilgilerin, doğruların rehberliğinde yaşayan bireyler işlevsel bir toplum oluşturabilmeye olanak sağlar.

Sosyal bilimlerin toplumsal işlevini sosyolojik olarak değerlendirmede Mills'in görüşleri de yol göstericidir. Mills'in "Sosyolojik İmgelem” kitabı görüşlerini açıklamış olduğu önemli bir eseridir. Burada "sosyolojik bakış açısı neyi ifade eder?" sorusunu öne çıkararak, toplumu anlayabilmek için sıradanlık konu olarak ele alındığında, sıradanlığın ötesine bakabilmeyi önermiştir (2000, s. 6). Onun yaklaşımı, daha öncede örnek olarak verilen, basit bir konu olan kahve üzerinden değerlendirilirse, batı ülkelerinde sabahları tüketilen, uyarıcı, aynı zamanda keyif verici bir içecek olarak, kahve insanlar arası iletişimi bağlılığı artırıcı bir etkiye sahiptir. Ancak kahve sosyolojik değerlendirme açısından çok daha derin inceleme konusu olabilir. Örnek olarak, kahve üretiminde çalışan işçiler, işçilerin hakları, sendikalaşma ve hak arayabilme durumları sosyolojik araştırma konusu olabilir. Yine uluslararası pazar, emperyalist ilişkiler gibi daha birçok boyutta değerlendirilebilir (Giddens, 2012: 40). Örneklerden de anlaşılacağı üzere, toplumsal olayların anlaşılabilmesi için toplumsal olgulara ve olaylara kahve örneğindeki kadar geniş bakabilmek gerekir.

Sosyolog imgelemi, kendisinin de içinde yaşıyor olduğu zamandan uzak tutarak, geçmişteki toplumların geçirdiği değişimleri dikkate alarak, gelecekteki toplumların geçirebileceği değişimleri kavramada bir araç olarak kullanmaya çalışır. Birey kendi yaşam 
öyküsüyle, toplumun kurumları arasındaki tarihsel gelişimin bağlantısını kavrayamazsa, kendisini de bireyler olarak algılayamayız. Bu açıdan bakıldığında "sosyolojik imgelem"; gündelik deneyimlerin yarattığı karmaşa içerisinde, daha uzun erimli bir tarih sahnesinde, toplumu oluşturan birbirinden farklı bireylerin iç dünyaları ve sosyal yaşamlarında taşıdıkları anlam dünyasında, bireylerin kendi deneyimlerini kavramalarını sağlar (Giddens, 2012: 41).

Ayrıca sosyolojik imgelem açısından bakıldığında, insanların yaşam koşulları, sosyal olaylar ve olgular, toplumsal yaşantıda bireylerin karşılaştıkları toplum kaynaklı sorunlar, zamanın değişmesiyle toplumsal koşullarda, insanların hayatında gerçekleşen değişimler, sosyolojik imgelem yoluyla değerlendirilmesi gereken konulardır. Çünkü sosyoloji, toplumu ve insan ilişkilerini incelerken, sosyolojik düşünebilmeyi öğrenmek, olaylara ve olgulara çok daha geniş açılardan bakabilmek biçiminde, imgelemin bilgi süreçlerimizle işlenmesini içermektedir. Derinlikli bir bakış açısı olan "sosyolojik imgelem"; öncelikle bireylerin kendilerini, gündelik hayatın bilinen sıradanlığından, yeniden bir yaklaşımla "uzaklaştırarak düşünmeyi" önermektedir. Sosyolojik imgelemin derinliği, yalnızca bireyi ilgilendirdiği sanılan, pek çok olayın gerçekte çok daha geniş sorunları yansıttığının görülebilmesini sağlar.

Örneğin sosyolojinin inceleme nesnesi olarak, toplumda yaşanmakta olan "işsizlik" olgusu irdelendiğinde; 10 milyon işsiz bulunan bir toplumda 3 milyon iş varsa, burada toplumsal ve yapısal ciddi bir sorun vardır. Böyle durumlarda bireylerin kendi girişimleri, çabalarıyla çözümlenemeyecek, toplumun yapısının, ekonomik, siyasal kurumlarının, sosyal sorunları var eden, yeniden üreten dinamiklerin yapısal özelliklerini incelemek ve geçerli bir açılama geliştirebilmek gerekir. Bu kapsamda yine değerlendirilmesi gereken, "yoksulluk", "işsizlik" gibi tüm toplumsal sorunların esas sebebinin, insanların kişisel başarısızlıkları dışında var olan, ekonomik, toplumsal sistemle ilişkisidir. Örnek olarak, kapitalist ekonomik sistemle ilişkisi paralelinde değerlendirildiğinde, büyük sermaye sahipleri daha çok gelir elde edebilmek için, çalışanlara daha az ödeme yapar, daha az ödeme yapabilmek için de, milyonlarca işsiz olmasını arzu eder. Buradaki örnekte görüldüğü gibi, her toplumsal sorunun kaynağında, toplumsal, ekonomik, siyasal, yönetimsel, kültürel vb. sistemle ilgili bir sorun bulunmaktadır. Her türlü toplumsal sorun da, sosyal bilimlerin problemi tespit, analiz ve çözme konusundaki çalışmalarına ihtiyaç duymaktadır. 
$\mathrm{Bu}$ kavrayışla, geniş kitlelerin mağduriyetleri ve olumsuz yaşam koşullarının, bizzat kendilerinin suçu olmadığı görülerek, toplumu oluşturan bireylerin yaşamlarının gerçek kodlarının, sosyolojik çözümlemelerle anlamlandırılması mümkün hale gelmektedir. Çünkü yoksulluk, işsizlik, açlık gibi ciddi toplumsal sorunların esas sebebi, insanların kişisel başarısızlıkları değil, geniş toplumun, kamunun, toplumsal güçlerin, sermaye sahiplerini ve devletin gücünü ele geçiren grupların tutumlarıdır. Öyleyse sosyolojik bakış açısı; kamu politikalarını reformlarla şekillendirilerek, toplumsal yaşamın işleyiş kodlarını yeniden düzenleyerek, toplumun pozitif yönde değiştirilebileceğinin görülebilmesini sağlayabilir.

Bugün toplumu anlamak, toplumsal sorunları analiz edebilmek için sosyal bilimler yeni bakış açıları geliştirmeye devam etmektedir. Örneğin post-modern görüş açısından değerlendirildiğinde, bilim insanlarının görevleri "gerçekten" ne olup bittiğini gözlemlemek ve anlamak olsa da, hepsi insandır ve gözlemlediklerine kendilerinden renkler verdikleri kişisel yönelimlere sahiptirler. Nihayetinde insanların dünyayı "gerçekten" olduğu gibi görmek ve anlamak için insanlıklarının dışına çıkmalarının hiçbir yolu yoktur (Babbie, 2008, s. 12). 1980'li yıllara gelindiğinde, post-modern bakış açıları güçlenmiş, bu farklı metodolojik bakışlar sosyal bilimler alanında araştırma konularını çeşitlendirmiş ve sosyal bilimlerin kendi içindeki sınırlarının geçişkenliğini, aralarındaki dayanışmayı, ilişkiyi artırmıştır. Yine, birçok teoride olduğu gibi, post-modern teorinin de, düşünürlere göre değişmekle birlikte eleştirilen çok yönü olmasına karşın, post-modern yaklaşımın buradaki katkısı ise, bilgiye, bilime ipotek koymaması, kesin doğruyu kabul etmemesi sebebiyle her görüşün kendini savunabilmesine olanak sağlaması şeklinde düşünülebilir.

Yine fizik bilimler ile sosyal bilimler topluma, insanlığa katkı açısından değerlendirilebilir. Fizik bilimlerin katkısıyla üretilen teknoloji sayesinde, üretimi artırmak, bu yolla da sürekli artan insan nüfusunun beslenmesini sağlamak, daha konforlu yaşamasını sağlamak olanaklı olmuştur. Gelecekte ise yapay zeka ve robotlarla desteklenen bir teknoloji dünyasının dünyayı şekillendireceği öngörülmektedir. Ancak, buraya kadarki paragraflardaki açınımlardan, tartışmalardan da anlaşılacağı gibi, sosyal bilimler olmadığ takdirde, fizik bilimlerin önemini kavrayacak insan yetiştirmek de olanaklı değildir. Ayrıca, toplumlarda var olan, eğitimden, sağlığa, insan hakları ihlallerine kadar birçok sorunda sosyal 
bilimlerin ufuk açıcı yaklaşımlarına ihtiyaç vardır. Örnek olarak, gelecekte işleri daha çok robotlar, yapay zekâ yapmaya başladığında, işsizlik vb. toplumsal sorunların çözümünde sosyal bilimlerin açınımları öne çıkacaktır. Anlaşılacağı üzere, sağlam temellere oturmuş bir sosyal bilim olmadığı takdirde, fizik bilimlerin gelişmesi de olanaklı değildir. Aynı kapsamda, güçlü bir sosyal bilim olmadığı takdirde, uluslararası sistemde, yeterince gelişememiş devletlerin, gelişmiş devletler seviyesine yükselmesi de mümkün değildir.

\section{TEKNOLOJIKK GELIŞMELER, TOPLUMSAL DEĞISşIM, GELIŞME VE SOSYAL BİLIMLER ETKÍLEŞIMİ}

Toplumsal değişme olgusu, toplumun nasıl işlediği ve değişik eylemlerin sonuçlarının neler olduğuna ilişkin anlayışları içeren bir kavramdır. Toplumların bireylerin değişmesine katkısı olduğu gibi, tek tek bireylerin de toplumsal değişmede katkısı olur. Toplumu en fazla değiştirme eylemine girişen insanlar, ellerinde çeşitli miktarlarda güç olan toplum üyeleri ya da güç sahibi insanlardır. Güç sahibi olmayan bireyler de toplumu etkileri seviyesinde değiştirirler. Kongar'ın açıklamalarına göre de, “Toplumsal değişme” tüm sosyal bilimler açısından çok önemli bir olgu olup, toplumun kendisi, kurumlarındaki yapısındaki temel ve geniş değişikliklerdir. Toplumsal yapı, insan-doğa ve insan-insan ilişkilerinin biçimlendiği, toplumsal kurumları da kapsayan yapı demek olduğundan, toplumbilimciler 'toplumsal değişmeyi', toplumun kendisi ve kurumlarında belirli bir zaman sürecinde meydana gelen değişimler olarak tanımlamaktadırlar. Kongar'a göre; “toplumun yapısı, toplumsal kurumların belirlediği toplumsal ilişkilerden meydana geldiğine göre, toplumsal değişme, temelinde teknolojik gelişme ve değişmelerin yattığı insanlar arası ilişkilerin değişmesidir". Öyleyse toplumsal değişme, teknolojik gelişmelerle temellendirilebilen, insanlar arası ilişkilerin, üretimle, tüketimle ilgili kalıpların, mülkiyeti öne çıkaran ilişkilerin, toplumsal değerlerin ve kuralların yeniden anlamlarkazandığı, kültür öğelerini de kucaklayan, geniş bir toplumsal yapı değişimi anlamına gelmektedir (2010: 160).

Kongar'ın toplumsal değişmeyle ilgili fikirlerinden de anlaşıldığı gibi, toplumsal değişmede teknolojik gelişmeler öne çıkmaktadır. Teknoloji her geçen zaman dilimlerinde, toplumsal, ekonomik hayatı önceki dönemlere göre çok daha fazla şekillendirmektedir. Özellikle günümüz dünyasında, bilgisayarlar, internet tabanlı uygulamalar, yapay zekâ, 
sosyal medya vb. insan hayatını bambaşka boyutlara taşımış, örnek olarak, bir zamanlar çok da üstünde durulmayan evden çalışma, pandemi sürecinin de katkısıyla gündemin merkezine yerleşen konulardan biri olmuştur. Teknoloji bir taraftan işgücüne ihtiyacı azaltırken diğer taraftan, yeni iş olanakları ortaya çıkarsa da, örneğin öngörüldüğü şekilde robotlar insan işgücüne ihtiyacı çok daha düşük seviyelere çekerse, işsizlik ve yoksulluk sebebiyle gelişen sosyal problemlerin nasıl çözüleceği belirsizdir. Günümüzün dünyasında insanlar arası ilişkiler kapitalist anlayış temelinde devam etmektedir. Kapitalizmin aşırı boyutlarındaysa, yoksullar, işsizler, sosyal güvencesi olmayanlar ya da yeterli düzeyde olmayanlar için, birçok toplumda, bu şekildeki toplumsal sorunların üstesinden gelecek mekanizmalar bulunmamakta veya işletilememektedir.

Toplumsal değişme ve gelişme ile ilgili, sosyal bilimler açısından tartışılması gereken önemli bir konu da, yaklaşımla ilgilidir. Burada iki yaklaşıma yer vermek uygun olacaktır. Bunlardan birincisi gelişme yazını, ikincisi ise azgelişme yazınıdır. Gelişme yazını yaklaşımında bulunanlar, azgelişmiş ülkelerin gelişmesi için, azgelişmiş ülkelere serbest piyasa ekonomisine geçilmesini, ekonomik sınırların esnekleştirilmesini, gelişmiş ülkeleri örnek almalarını önermektedir. Azgelişme yaklaşımı ise, toplumsal ekonomik açıdan her ülkenin farklı koşulları olduğunu vurgulamakta, bağımlılık teorilerinde açıklanan gelişmiş ülkeler ile azgelişmiş ülkeler arasındaki ilişkinin çıkara dayalı ilişkisini açıklamaya çalışarak, aslında azgelişmiş ülkelerin dikkatli olmaması durumunda, bu ilişkiden zararlı çıkacaklarını ispatlamaya çalışmaktadırlar (Er, 2015, s. 3). Yine toplumsal gelişme ve değişmeyi anlamak için Er'in makalesinde konu edildiği gibi, üretim ilişkilerinin kültürle bağlantısını açılamak gerekmektedir. Özellikle 20. Yüzyıl dikkate alındığında, üretim ilişkileri bağlantısında fordist üretim sistemi etkisiyle gelişen, kurgulanan, modernite kültürünü ve post-fordist üretim sistemi etkisiyle gelişen, kurgulanan post-modernite kültürünü anlamak önemlidir (2015).

Yine modernleşme literatüre bakıldığında, yenileşmeyle, çağdaşlaşmayla, ilerlemeyle, kalkınmayla, gelişmeyle ilgili değer yargıları çağrıştıran bir kavram olarak ortaya çıkmaktadır. Yani yukarıda açıklaması yapılan gelişme yazınına uygun olarak açıklanırsa, daha çok azgelişmiş ülkelerin, toplumsal, kültürel, ekonomik, siyasal vb. endüstrileşmiş ülkelerin modellerini benimsemeleri ve onlara benzemeleriyle ilgili süreci anlatır. Modernleşme, bu 
yaklaşıma göre, yeterince gelişememiş ülkelerin gelişmiş ülkelerin izinden giderek onlara yetişmeye çalışmasıyla açıklanmaya çalışılmaktadır (Özkalp, 2004, s. 152). Modernleşme sürecini tamamlayan toplumların, akla öncelik verdikleri söylenebilir. Modernleşmeyle ilgili önemli görüşleri olan Weber'e göre ise "akılcılık"; toplumların olaylar karşısında nasıl hareket ettiği, duygusal, geleneksel davranışlar yerine neden sonuç ilişkileri paralelinde gelişen rasyonel inançların yerleştiği bir yapıyı açıklamaktadır. Geleneksel toplumlarda ise, modern toplumlarla karşılaştırıldığında, yavaş bir değişim olmakta, farklı bakış açılarını değerlendirmeme anlamında dini bağlılıklar yüksek görünmektedir. Ayrıca geleneksel toplumlar, endüstrileşmenin zayıf olduğu, kırsal tarım üretiminin yoğun ve tarımda teknolojinin kullanılamamasından kaynaklı yoksulluğun süre gittiği sorunları yaşamaya devam etmektedir (Henslin, 1997; akt. Özkalp, 2011).

Ergil' in akılcı ve rasyonel bir toplumla ilgili aktardıklarına göre de, toplumun tarihsel süreçte Avrupa' da sanayileşmenin gelişmesiyle "dinde reform" ve toplumun hızlı bir şekilde laikleşmesi gerçekleşmiş, kilisenin siyasi gücünü kaybetmesi sağlanmış, vicdan statüsünde “manevi bir kuruma” dönüşmesi sağlanarak akılcl, rasyonel bir topluma ulaşılabilmesi gerçekleştirilebilmiştir (2012). Buradaki yaklaşım farklılıklarıyla da anlatılmaya çalışıldığı gibi, her ülkenin modernleşme süreçleri açısından, bazı benzerlikleri olmasına rağmen, her ülke kendi ekonomik ve toplumsal koşulları çerçevesinde, kendi kültürüne özgü bir modernleşme sürecini dikkate almalıdır. Çünkü her toplumun endüstrileşme seviyesi, kültürü ve diğer toplumsal koşulları farklıdır.

Bu bölümde de açıklanmaya çalışıldığı gibi, özellikle de çok hızlı gelişen teknolojik alt yapının toplumlara etkileri paralelinde, toplumsal değişme ve gelişme tüm toplumların dikkate alması gerekli konulardır. Ve bu anlamda tüm toplumlar, değişmenin, gelişmenin kendi toplumlarının yaşantısını kolaylaştırma, güzelleştirme anlamında daha iyiye gitmesini bekler. Yine tüm toplumsal değişme ve gelişmeler, yukarıdaki metinlerde de açıklanmaya çalışıldığı gibi, sosyal bilimlerle etkileşimle birlikte değerlendirildiğinde açıklanabilmekte, sorunların çözümüyle ilgili açınımlar sağlanabilmektedir. Sosyal bilimlerin bir ülkede güçlü olması, toplumsal yapıdaki diğer her şeyin de güçlü olmasına olanak sağlar. Çünkü bu yolla, toplumsal sorunlara sıradan çözüm üretmek yerine, bilimsel teorilerin, yaklaşımların, araştırmaların katkısıyla çözümler üretilebilir. 


\section{TARTIŞMA ve SONUÇ}

İnsanlar gerçekliği sosyal olarak inşa ederlerken, sosyal etkileşim yoluyla, yaratıcı bir biçimde şekillendirirler. Sosyal etkileşim, gerçeği inşa eden karmaşık bir anlaşmadır. İnsanlar, gündelik yaşamlarında, örnek olarak diğer insanlarla, karşı cinsle ilişkilerinde duygusal ilgi hissettirirler, ilgilenirler, geri çekilirler ve bütün bunlarla, çevrelerini anlamlandırmaya çalışırlar. İnsanlar gerçekliği, onları çevreleyen kültüre göre inşa ederler ve bu inşa, her zaman gerilimleri, ayrımları kapsamaktadır.

Toplumları yöneten şeyler, aslında değerlerdir ve "değerler", bir şeyin önemini açıklamada kendini gösteren, soyut ölçüler, karşılıklardır. Toplumların şekillenmesinde önemli bir yere sahip olan değerler, ahlaksal, ruhsal, toplumsal güzellikleri temsil edebileceği gibi, tam tersini de ifade edebilir. Bilimsel değerler ise, bilgiye, gerçeğe, muhakemeye ve eleştirel düşünceye önem vererek öne çıkar. Bir toplumun, bilimsel ve akılcı düşüncelere mi önem verdiği, yoksa büyü, boş inançlar benzerlerine mi yüksek bir yatırım yaptığı konusu, toplumun yazgısını belirleyen en önemli unsurdur. "Toplum”; değerler üzerine kurulmuş bir yapıdır. Toplumun ortak değerleri ve kuralları, o toplumun bireylerine aidiyet ve kimlik kazandırır.

Toplumsal yaşam, kaos, karmaşa, belirsizliği kaldıramaz; daima, düzenlilik ve sürekliliğe meyleder. İlkel toplumlarda totem, tabu; köleci toplumlarda din; imparatorluklarda din ve ahlâk; ulus devletlerde ise anayasa ve kanunlarla toplumsal düzen sağlanmaya çalışılmıştır. Devlet, toplumsal farklılaşmanın, toplumsal eşitsizliğin yapılaştığı ve kurumlaştığı bir yapıdır. Egemenliğin yapısı, üretim ilişkilerini ve toplumsal zenginliğin "nasıl dağıtılacağını" belirler. Nerede bir egemenlik/iktidar ilişkisi varsa; orada sömürü ve istismar vardır ve bu ilişki, egemenliği pekiştirirken, aynı zamanda onu yeniden üretir ve kurumsallaştırır. Devlet kimlerin ve hangi grupların elindeyse, kurulmuş bu yapı onlara hizmet edecektir. Bu çerçevede, devletin niteliğini belirleyen olgu da "toplumun yapısından" başka bir şey değildir. Bu doğal eşitsizlik düzeninde hukuk da, kimlerin hangi konuda nasıl ve ne derecede karar alacağı, kimlerin kontrol edileceğini belirleyen bir nitelik gösterecektir (Özerkmen, 2007). 
Dünyada, sosyal bilimlerin, sosyolojinin bilim dünyasındaki yerini almasında öne çıkan düşünce iklimi, dünya tarihinin akışını ardından sürükleyen 1783 Amerikan Devrimi, devamında 1789 Fransız Devrimi'nin etkisiyle gerçekleşen toplumsal düzlemde oluşmaya başlamış; sosyal tarihin ve işleyişin kodlarının anlaşılmasını sağlamıştır. Tarihsel süreçte yaşanan gelişmelerle birlikte, toplum bireyi yaratıp var ederken; eşzamanlı olarak bireyler de toplumun dinamiklerini, işleyiş mekanizmalarını ve temel sosyal kodlarını, alışkanlık, değer, düşünce biçimleri ve davranışlarıyla inşa etmişlerdir.

Modern toplumlarda yaşayabilmek için, toplumu oluşturan diğerlerine güven duyabilmek gereklidir. Çiftçilere, imalat yapanlara, esnaflara, besin uzmanlarına, tüccarlara, uzmanlara, profesyonellere ve devlet birimlerine güvenilmek zorundadır. Politikacilar, uzmanlar, kamu yöneticileri ve diğer yetkililere karşı kapsamlı bir güven kaybı yaşanması, toplumsal düzenin sorgulanmasına ve memnuniyetsizlikler ortaya çıkmasına sebep olur.

Doğrusu "sosyoloji"; topluma bakarken temel bir düşünceden yola çıkmıştır: "Eğer, olaylar şu an oldukları gibi olmak zorunda değillerse, o zaman kesin bir biçimde daha iyi ve ideal olabilirler". Bu önerme, toplumların bilgiyle, insan düşüncesiyle, olduğundan daha farklı ve işlevsel yapılandırılabilmesinin olanaklılığını, değişim ve dönüşüm olgularının, insanın yeryüzü yaşamının doğal bir parçası olduğunu ortaya koymaktadır. Bu paradigmalardan hareketle, bir bilim dalı olarak "sosyoloji"; toplumsal gerçekliği daha iyi anlayıp, açılayabilmemizi ve daha iyi bir toplum kurabilmemizin ipuçlarını bulabilmeyi konu edinmektedir. Bu çerçevede, sosyal bilimlerin analiz ve sentezlerini, sosyal çözümlemelerini inceleyerek, bireysel ve toplumsal yaşamlarını daha işlevsel ve başarılı hale dönüştürmek isteyen bireyler ya da toplumlar, edinmiş oldukları bu bilgi ve değer gücüyle, geleceklerini daha pozitif biçimde şekillendirebilirler. Bir toplumdaki gelişmeyi ve pozitif değişimi yaratan, o toplumun iç ve dış sömürüyü bırakarak, geliri tabana yayabilmesi ve tüm yurttaşlara eşit fırsat ve olanaklar yaratabilmeyi başarmasıdır (Acemoğlu ve Robinson, 2016: $40)$.

Sosyo-ekonomik gelişmeye ulaşabilmek için, toplumların, kelimenin gerçek anlamıyla “modern" bir ülke sistemi inşa edebilmesi gerekmektedir. Böyle bir düzlemde, yurttaşlar nesne olmaktan çıkarak "özne" olur ve dini kendi çıkarları için istismar edenlerin, halkı 
kandırarak, uyutarak sahtekârlıkla geçinenlerin yerini, kamu yöneticileri, hekimler, öğretmenler ve sosyal bilimciler alır. 1923’de Kemalist Devrim, Türkiye'de böyle bir modernleşme inşası amacıyla gerçekleştirilmiş, ancak son elli yılda bu paradigmalardan kademeli olarak feragat edilerek, süreç akamete uğratılmıştır (Akın, 1989: 56 ve Akşin, 2000). Çünkü teokratik devlet anlayışından, demokratik devlet anlayışına, cumhuriyete biçim olarak geçilmiştir. Geniş kitleler, eğitim seferberliği ve yurttaşlara geniş olanaklar yaratılarak, sivil toplum inşa edilerek, bu modern anlayışların toplum temelinde inşası gerçekleştirilmek istenmiştir. Ancak, bilimin rehberliği yerine çıkar oyunlarının, halkın kültürüyle ilgili zaaflarının kullanılmasıyla tam bir başarı sağlanamamıştır (Arsel, İ., 1993; Manisalı, 2009; Berkes, 2016,). Esasında, dünya ölçeğinde "küresel sömürü" de bu mekanizmalar üzerinden işletilmekte ve toplumların kendi sosyolojileri ve sosyal bilimlerini kurarak, akılcl, rasyonel düşünüp davranabilen devlet-toplum yapılarının kurulması, bir şekilde bloke edilmektedir (Tokalak, 2016). İşlevsiz toplumsal yapılar yaratılarak, görünüşte modernliğin birçok unsuru bir simülasyon biçiminde sahnede iken, içerikte hep çıkmazlar, açmazlarla harmanlanmış “işlevsiz toplumsal kurumlar, yapılar ve aktörler” bulunmaktadır (Yolcuoğlu, 2013).

Modernleşmenin en önemli unsuru olarak Habermas'ın (2000) vurguladığı "hukuksallaşma" ve gerçek anlamda bir hukuk devleti inşası da hiçbir zaman layıkıyla yaşama geçirilememiştir. Oysa, 18. Yüzyıldan sonra modern dünyaya egemen olan Aydınlanmanın elifbası, "aklın bir gereç olarak kullanılması" ve akıl ve bilgi yoluyla yeni bir dünyanın yaratılmasıdır (Cevizci, 2008: 67). Türkiye'de ise, Kemalist Devrim sonrasında, modernleşme kuramları çerçevesinde, bilimsel paradigması, kendisini koruyabilen akılcı paradigmalarıyla modernleşme sürecini tamamlamış bir Türkiye inşa edilmemiştir (Kongar, 2010). Modern Batı sisteminde de dine dayalı yönetimlerin, kurumların yerini, birey haklarının, demokrasinin, bilimin alması çok kolay olmamış, çok bedellerin ödendiği zorlu süreçler, kaoslar yaşanarak süreç tamamlanabilmiştir (Stremlin, 2007).

Göle (2008: 8-13)'nin belirttiği gibi; “Türkiye'de sosyal bilimler, modernleşmeci Cumhuriyet elitlerinin, kalkınma mantığıyla hareket ederek, mühendislik ve teknik bilgilere daha fazla önem göstermesi nedeniyle, bütün dünyada olduğu gibi, ikincil bir düzeyde ele alına gelmiştir." Oysa buradaki çalışmada da vurgulandığı gibi, bir ülkede sosyal bilimler 
sağlam bir temele oturup, yaygınlaşmadığı takdirde, o ülkede sosyo-ekonomik gelişme de olması gerektiği gibi olmayacaktır.

Makalenin buraya kadar olan kısmında, teknolojik gelişmelerin başat rol oynadığ1 toplumsal gelişme açısından, sosyal bilimlerin işlevi ve toplumla etkileşimi, sosyal bilimlerin sosyo-ekonomik gelişmeye katkısı, bilimin gelişmesine katkısı incelenmeye çalışılmıştır. Aynı kapsamda fizik bilimlerin ve teknolojinin gelişmesi için de sağlam temellere oturmuş bir sosyal bilimin neden çok önemli olduğu üzerinde durulmuştur. Konuyu açabilmek için, birçok düşünürün, sosyoloğun, görüşlerine yer vererek sosyal bilimlerde ve genel olarak bilimde yaşanan karmaşalarla ilgili açınımlar geliştirmeye çalışılmıştır. Bu kapsamda bilimsel yöntem, ilke, yaklaşımlar üzerinde durulmuş, bilim ve bilim olmayanın ayırdı, bazı teorisyenlerin görüşleri de değerlendirilerek açıklanmaya çalışılmıştır. Ayrıca teknolojinin büyük etki ettiği toplumsal değişim ve gelişmenin sosyal bilimlerle olan etkileşimine yer verilerek, sosyal bilimlerle toplumsal gelişmeler, değişmeler arasında nasıl bir etkileşim olduğu değerlendirilmiştir.

Son söz olarak toparlanırsa, bir toplumun "neye değer verdiği", neye yatırım yapıp önemsediği, hangi düşünceleri tutumları benimsediği, bilimsel, rasyonel düşünceye yatkın olup olmadığı konuları, o toplumun, ülkenin yazgısını, toplumsal yaşamını, bugününü ve yarınını belirleyen en önemli ölçüttür. Bu da toplumun kültürünün, eğitiminin bilimsel yöntem ve ilkelere göre kurulmuş olması, sosyal bilimlere gerekli değerin verilmesiyle olanaklı olur. Makalede anlatılmaya çalışıldığı gibi, bir toplumun gelişmesi, toplumdaki insanların barış içinde, daha adil geçim şartlarında, mutlu yaşaması için sosyal bilimlerin olması gerektiği yerde olması ve toplumsal gelişmeye gereken katkıyı verebilmesi gerekir. Yine karanlık yapıların, çıkar çevrelerinin bilimi de kendi egemenliklerine alarak, yalancı bir aydınlanmayla toplumu kandırmamaları için, insan hak ve özgürlüklerinin, demokrasinin, hukuk devletinin tüm mekanizmalarıyla sağlıklı işlediği bir yapılanma gerekir. Çünkü fikir özgürlüğü olmayan yerde karanlık vardır. Karanlıkta ise gerçeği bulmak zordur. "Kurt puslu havayı sever" özdeyişinde de olduğu gibi, geçimlerini yalandan, insanların eğitimsizliğinden sağlayan insanların önü açılmış olur. Tüm bunlar ve zamanımızda teknolojik gelişmelerin hızla değiştirdiği, toplumsal ilişkiler, sorunlar, bu hızlı değişikleri zamanında açıklayabilen, 
olası toplumsal sorunlara çözüm üretebilen sosyal bilim yaklaşımlarını gerekli kılmaktadır.

\section{KAYNAKÇA}

Acemoğlu, D. ve Robinson, J. A. (2016). Ulusların Düşüşü- Göç, Zenginlik ve Yoksulluğun Kökenleri. (15. Baskı), İstanbul: Doğan Kitabevi.

Aron, R. (2014). Sosyolojik Düşüncenin Evreleri. (9. Baskı). (K. Alemdar, Çev.), İstanbul: Kırmızı Yayınları. Akın, İ. F. (1989). Türk Devrimi Tarihi. İstanbul: Beta Yayınları.

Akşin, S. (1997). Siyasal Tarih (1789-1908). Türkiye Tarihi Cilt 3: Osmanlı Devleti 1600-1908, İstanbul: Cem Yayınevi.

Akşin, S. (2000). Ana Çizgileriyle Türkiye'nin Yakın Tarihi. 1789- 1980. Ankara: İmaj Yayınları.

Aron, R. (2004). Sosyolojik Düşüncenin Evreleri. Ankara, Bilgi Yayınevi.

Arsel, İ. (1993). Teokratik Devlet Anlayışından Demokratik Devlet Anlayışına-Şeriat Devletinden Laik Cumhuriyete. İstanbul: Kaynak Yayınları.

Aydın, M. (2000), Kurumlar Sosyolojisi. (2. Baskl), Ankara: Vadi Yayınları,

Aziz, A. (2008). Sosyal Bilimlerde Araştırma Yöntem ve Teknikleri. Ankara: Nobel Yayın Dağıtım Ltd. Şti.

Bhushan, V., S., D. R. (2016). Fundamentals of Sociology. Pearson Education India.

Babbie, E. R. (2008). The Basics of Social Research. (4th ed). Thomson/Wadsworth.

Brubaker, R. (2006). The Limits of Rationality: An Essay on The Social and Moral Thought of Max Weber. Routledge.

Bauman, Z. (2014). Sosyolojik Düşünmek. Sosyoloji Başlangıç Okumaları İçinde. Edt. A. Giddens. İstanbul: Say Yayınları.

Berkes, N. (2016). Teokrasi ve Laiklik. İstanbul: YKY Yayınları.

Cevizci, A. (2008). Aydınlanma Felsefesi Tarihi. Bursa: Asa Kitabevi.

Durkheim, É, Gouldner, A. W., Sattler, C., \& Mauss, M. (2010). Socialism and Saint Simon. Routledge. http://search.ebscohost.com/login.aspx?direct=true\&scope=site\&db=nlebk\&db=nlabk\&AN=28 9934 
Eagleton, T. (1991). Ideology: An Introduction. London ; New York: Verso.

Elster, J. (1986). An Introduction to Karl Marx. Cambridge University Press.

Ergil, D. (2012). Toplum ve İnsan: Toplumbilimin Temelleri. İstanbul: Hayat Akademi.

Er, K. (2015). Üretim İlişkileri Temelinde Modernizm ve Post-Modernizmin Azgelişmiş Ülkeler Üzerine Etkileri. Dokuz Eylül Üniversitesi Sosyal Bilimler Enstitüsü Dergisi, 16 (3), 413. https://doi.org/10.16953/deusbed.39137

Ferris, K., \& Stein, J. (2018). The Real World: An Introduction to Sociology. (Sixth edition). W.W. Norton.

Giddens, A. (2012). Sosyoloji. (1. Baskl), Çev. (Grup), İstanbul: Kırmızı Yayınları.

Gulbenkian Komisyonu Raporu. (2003). Sosyal Bilimleri Açın: Sosyal Bilimlerin Yeniden Yapılanması Üzerine Rapor. (4. Baskı), (Ş. Tekeli, Çev.) İstanbul: Metis Yayınları.

Göle, N. (2008). Mühendisler ve İdeoloji: Öncü Devrimcilerden Yenilikçi Seçkinler.

(4. Baskı), İstanbul: Metis Yayınları.

Habermas, J. (2000). Kamusallı̆ı̆n Yapısal Dönüşümüu. (T. Bora ve M. Sancar, Çev.), (3. Bask1), İstanbul: İletişim Yayınları.

Hegel, G. W. F. (2018). Georg Wilhelm Friedrich Hegel: The Phenomenology of Spirit. (T. Pinkard \& M. Baur, Ed.; 1. bs). Cambridge University Press. https://doi.org/10.1017/9781139050494

Haviland, W. A. Prins, H, E., Walrath, D., Mcbride B., (2008). Kültürel Antropoloji. (D, İnan, Çev.) Erguvan Sarığlu, İstanbul: Kaknüs Yayınları.

Kongar, Emre. (2010). Toplumsal Değişme Kuramları ve Türkiye Gerçeği. (14. Baskı), İstanbul: Remzi Kitabevi.

Manisalı, Erol. (2009). Dünya'da ve Türkiye'de Büyük Sermaye. İstanbul: Bilgi Yayı- nevi.

Mills, C, W. (2000). The Sociological Imagination. New York: Oxford University Press.

Macionis, J. J. (2018). Sociology. (Sixteenth Edition, Global Edition). Pearson.

Musso, P. (2017). Religion and Political Economy in Saint-Simon. The European Journal of The History of Economic Thought, 24 (4), 809-827. https://doi.org/10.1080/09672567.2017.1332666

Neuman, W. L. (2007). Basics of Social Research Qualitative and Quantative Aproaches (2. bs). Pearson 
Education, Inc'.

Özerkmen, N. (2007). Toplumsal Sorunlara Sosyolojik Bakışlar. Ankara: Asil Yayın Dağıtım.

Özkalp, E. (2011). Sosyolojiye Giriş. Bursa: Ekin Kitabevi Yayınları.

Özkalp, E. (2004). Davranış Bilimlerine Giriş. (3.Baskı), Eskişehir: Anadolu Üniversitesi Yayınları.

Popper, K. R. (1971). The Open Society and Its Enemies. (5. ed., 1. paperback print). Princeton Univ. Press.

Smart, B., \& Ritzer, G. (Ed.). (2001). Handbook of Social Theory. London: SAGE Publications Ltd.

Stremlin, B. (2007). Otoritenin Kuruluşu: Modern Dünyada Bilimin Yükselişi.

Tischler, H. L. (2011). Introduction to Sociology. (10th ed). Wadsworth, Cengage Learning.

Tokalak, İ. (2016). Küresel Sömürü. İstanbul: Ataç Yayınevi.

Turner, B. S. (1999). Classical sociology. London, SAGE Publications.

Wallerstein, I. (2007). Modern Dünya Sistemi I. İstanbul: Yarın Yayıncılık.

Yolcuoğlu, İ, G. (2013). Toplumsal İşlevsizlik. İstanbul: Nar Yayınevi.

Yolcuoğlu, İ. G. (2019). Sosyal Hizmet / Sosyal Çalışma Bilim ve Mesleğine Giriş. (4. bs). İstanbul: Nar Yayınevi. 